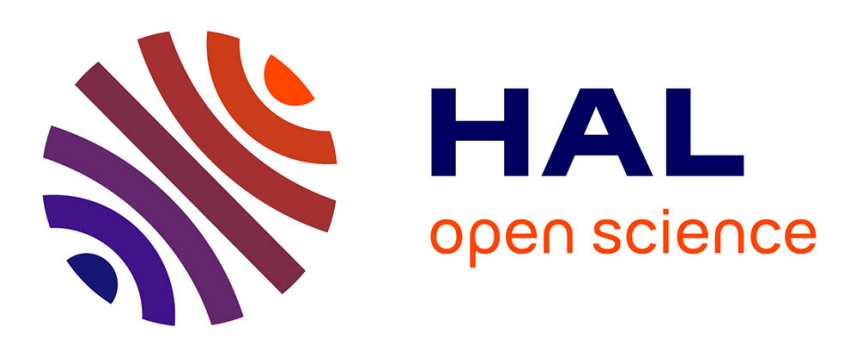

\title{
Development of antibody fragments for immunotherapy of prion diseases
}

\author{
Vincenza Campana, Lorena Zentilin, Ilaria Mirabile, Agata Kranjc, Philippe \\ Casanova, Mauro Giacca, Stanley Prusiner, Giuseppe Legname, Chiara \\ Zurzolo
}

\section{To cite this version:}

Vincenza Campana, Lorena Zentilin, Ilaria Mirabile, Agata Kranjc, Philippe Casanova, et al.. Development of antibody fragments for immunotherapy of prion diseases. Biochemical Journal, 2009, 418 (3), pp.507-515. 10.1042/BJ20081541 . hal-00479077

\section{HAL Id: hal-00479077 https://hal.science/hal-00479077}

Submitted on 30 Apr 2010

HAL is a multi-disciplinary open access archive for the deposit and dissemination of scientific research documents, whether they are published or not. The documents may come from teaching and research institutions in France or abroad, or from public or private research centers.
L'archive ouverte pluridisciplinaire HAL, est destinée au dépôt et à la diffusion de documents scientifiques de niveau recherche, publiés ou non, émanant des établissements d'enseignement et de recherche français ou étrangers, des laboratoires publics ou privés. 


\section{DEVELOPMENT OF ANTIBODY FRAGMENTS FOR IMMUNOTHERAPY OF PRION DISEASES}

V. Campana*, L. Zentilin ${ }^{\dagger}$, I. Mirabile ${ }^{\ddagger}$, A. Kranjc ${ }^{\ddagger}$, P. Casanova*, M. Giacca ${ }^{\dagger}$, S.B. Prusiner $^{\S}$, G. Legname* and C. Zurzolo*.

*Unité de Trafic Membranaire et Pathogénèse, Institut Pasteur, 25 rue du Docteur Roux, 75724 Paris Cedex 15, France; 'International Centre for Genetic Engineering and Biotechnology (ICGEB), Padriciano 99, 34012 Trieste, Italy; ${ }^{\ddagger}$ Scuola Internazionale Superiore di Studi Avanzati - International School for Advanced Studies (SISSA-ISAS), I-34014 Trieste, Italy; ${ }^{\S}$ Institute for Neurodegenerative Diseases, Department of Neurology, University of California San Francisco, San Francisco, CA 94143, U.S.A.

\section{SHORT TITLE: ScFv IN PRION DISEASE THERAPY}

Corresponding Author: Chiara Zurzolo, Unité de Trafic Membranaire et Pathogénèse, Institut Pasteur, 25 rue du Docteur Roux, 75724 Paris Cedex 15, France. Tel: (33) 01 45688277. Fax: (33) 01 40613238.E-mail: zurzolo@pasteur.fr 


\section{SYNOPSIS}

Prions are infectious proteins responsible for a group of fatal neurodegenerative diseases called transmissible spongiform encephalopathies (TSEs), or prion diseases. In mammals, prions reproduce themselves by recruiting the normal cellular protein $\left(\operatorname{PrP}^{\mathrm{C}}\right)$ and inducing its conversion to the disease-causing isoform denominated $\mathrm{PrP}^{\mathrm{Sc}}$. Recently, anti-prion antibodies have been shown to permanently cure prion-infected cells. However, the inability of full-lenght antibodies and proteins to cross the bloodbrain barrier (BBB) hampers their use in the therapy of TSEs in vivo. Alternatively, brain delivery of prion-specific scFv by adeno-associated virus (AAV) transfer delays the onset of the disease in infected mice, although protection is not complete.

We investigated the anti-prion effects of a recombinant anti-PrP (D18) single-chain variable fragment $(\mathrm{scFv})$ by direct addition to scrapie infected cell cultures or by infection with both lentivirus and adeno-associated virus (AAV) transducing vectors. We show that recombinant anti-PrP $\mathrm{scFv}$ is able to reduce proteinase K-resistant PrP content in infected cells. In addition, we demonstrate that lentiviruses are more efficient than AAV in gene transferring of the anti-PrP scFv gene and in reducing $\mathrm{PrP}^{\mathrm{Sc}}$ content in infected neuronal cell lines. Finally, we have used a bioinformatic approach to construct a structural model of D18scFv-PrP ${ }^{\mathrm{C}}$ complex. Interestingly, according to the docking results, $\operatorname{Arg}_{\mathrm{PrP}} 151$ (Arg151 from prion protein) is the key residue for the interactions with $\mathrm{D} 18 \mathrm{scFv}$, anchoring the $\operatorname{PrP}^{\mathrm{C}}$ to the cavity of the antibody.

Taken together, these results indicate that combined passive and active immunotherapy targeting $\mathrm{PrP}$ might be promising strategies for therapeutic intervention in prion diseases.

KEYWORDS: Adeno-associated Virus, Immunotherapy, Lentivirus, $\operatorname{PrP}^{\mathrm{C}}, \operatorname{PrP}^{\mathrm{Sc}}$, ScFv.

ABBREVIATIONS FOOTNOTE: AAV: adeno-associated virus; BBB: blood-brain barrier; BSE: bovine spongiform encephalopathy; CJD: Creutzfeldt-Jakob disease; CNS: central nervous system; Fab: antigen-binding fragment; IPTG: isopropyl-betathio-galactoside; $\mathrm{PK}$ : proteinase $\mathrm{K}$; $\mathrm{PrP}^{\mathrm{C}}$ : cellular prion protein; $\mathrm{PrP}^{\mathrm{Sc}}$ : scrapie prion protein; scFv: single-chain variable fragment; TSE: transmissible spongiform encephalopathy 


\section{INTRODUCTION}

Transmissible spongiform encephalopathies (TSEs) or prion diseases are fatal neurodegenerative disorders that affect humans and animals. The mechanisms involved in their pathogenesis are not completely understood, but they are associated with the accumulation in the brain of a misfolded form, $\mathrm{PrP}^{\mathrm{Sc}}$, of the endogenously expressed cellular prion protein $\left(\mathrm{PrP}^{\mathrm{C}}\right)$ [1]. Industrial cannibalism has been responsible for one of the most infamous TSE epidemics, bovine spongiform encephalopathy (BSE), paralleled with an increasing number of human cases with a variant form of Creutzfeldt-Jakob Disease (vCJD) from BSE-contamined beef products [2].

Direct interaction between the pathogenic $\mathrm{PrP}^{\mathrm{Sc}}$ template and the endogenous $\mathrm{PrP}^{\mathrm{C}}$ substrate and the following conformational conversion of $\operatorname{PrP}^{\mathrm{C}}$ into $\mathrm{PrP}^{\mathrm{Sc}}$ are proposed to drive the formation of nascent infectious prions [3]. Various lines of evidence indicate that the process of conversion is the key element in pathogenesis. Knockout mice $\left(P r n p^{0 / 0}\right)$ are resistant to prion diseases and do not propagate infectivity [4], as well as brain tissue homogenate from $\operatorname{Prnp}^{0 / 0}$ cows are resistant to prion propagation in vitro [5]. Moreover, Prnp $p^{0 / 0}$ brain tissue surrounding prion-infected Prnp ${ }^{+/+}$ neurografts does not develop neuropathological changes typical of prion diseases [6]. Over the past several years, many anti-prion compounds have been identified in in vitro models of prion replication, such as polysulphated polyanionic compounds, polyamine, tetrapyrroles, polyene antibiotics, peptides, tetracyclic and tryciclic compounds. These prion antagonists can be targeted towards the selective binding of $\operatorname{PrP}^{\mathrm{C}}$ or $\mathrm{PrP}^{\mathrm{Sc}}$ and/or to the process of conversion (reviewed in [7-9]). However, most of these molecules were found to be toxic or ineffective in animal models of prion diseases (reviewed in [7-9]).

Interestingly, by taking advantage of the 'prion-resistant' polymorphisms Q171R and E219K that naturally exist in sheep and humans, respectively, a therapeutic approach based on the use of lentiviral vectors carrying mouse Prnp mutated gene has recently been evaluated [10]. The expression of these PrP variants, acting as dominant negative, inhibits prion replication in permanently prion-infected cells and in animals [10]. In addition, suppression of PrP expression by lentiviral vector-mediated RNAi prolongs survival of scrapie infected mice [11].

Alternatively, anti-prion protein $(\mathrm{PrP})$ antibodies have been shown to have an antiprion effect in cellular and animal models [12-15]. Early indications of the potential of antibody therapy for prion disease came from in vitro studies, showing reduction in infectivity of prions after incubation with an anti-PrP antibody [16]. Immunization with $\operatorname{PrP}$ peptides reduced $\mathrm{PrP}^{\mathrm{Sc}}$ in a peripheral model of mouse scrapie [17]. Different publications report that antibodies directed against the middle portion of PrP (residues 91-110 and 132-156) can cure scrapie infected cells in culture and reduce proteinase K (PK)-resistant PrP in spleens of infected mice (reviewed in [12, 13, 18]. In cell systems, anti-prion antibodies were able to purge the cells entirely of $\operatorname{PrP}^{\mathrm{Sc}}$ [12] and their potency correlated with their ability to recognize the total population of $\operatorname{PrP}^{\mathrm{C}}$ molecules on the cell surface. Despite these encouraging results, development of effective immunotherapy presents several problems both in active and passive approaches. An important obstacle in the development of efficacious regimens for active immunization is host tolerance to endogenous $\operatorname{PrP}^{\mathrm{C}}$, which limited the therapeutic efficacy of this immunization approach $[15,19]$. In comparison, passive immunization suffers from the intrinsic problem of poor antibody diffusion from vessels into tissues, especially in the nervous tissue: administration of monoclonal antibodies has been shown to prevent the pathogenesis only when applied 
simultaneously, or shortly after, peripheral prion infection [18]. Moreover, production of large amounts of monoclonal antibodies for therapy is technically challenging and expensive.

In 2001, Peretz and co-workers [12] analyzed the ability of some recombinant antibody antigen-binding fragments (Fabs) to inhibit prion propagation in a cultured mouse neuroblastoma cell line infected with $\operatorname{PrP}^{\mathrm{Sc}}(\mathrm{ScN} 2 \mathrm{a})$. The most effective Fab, $\mathrm{D} 18$, was found to abolish prion replication and to clear pre-exiting $\operatorname{PrP}^{\mathrm{Sc}}$, eliminating $50 \%$ of $\mathrm{PrP}^{\mathrm{Sc}}$ from the cells within about 24 hours. The activity of D18 was attributed to its ability to specifically recognize the total population of $\operatorname{PrP}^{\mathrm{C}}$ molecules on the cell surface. In $\operatorname{PrP}^{\mathrm{C}}$, the D18 epitope spans residues 132-156 and incorporates helix A. This sequence lies within the region of the protein thought to bind $\mathrm{PrP}^{\mathrm{Sc}}$, an essential step for prion propagation: therefore, it can be argued that D18 operates mechanistically by directly blocking or modifying interaction of $\operatorname{PrP}^{\mathrm{C}}$ with $\operatorname{PrP}^{\mathrm{Sc}}$ [12]. Compared to full-length antibodies, Fabs are smaller molecules and their monovalent nature may be beneficial, since intracerebral injection of some anti-PrP immunoglobulin $\mathrm{G}$ (IgG) antibodies seemed to provoke neuronal apoptosis [20]. However, their effectiveness in prion disease therapy in vivo has not yet been evaluated. The major problem in using anti-prion molecules in vivo is that peptide and protein therapeutics are generally excluded from transport to the brain, owing to the negligible permeability of these drugs to the brain capillary endothelial wall, which makes up the blood-brain barrier (BBB) in vivo. Fab fragments did not penetrate through the BBB, unless they are hydrophobized by adding stearoyl chloride [21] or cationized [22]. One promising solution to this problem is offered by the use of single chain variable fragments or scFv. ScFv are monovalent mini-antibodies, constituted by a single fusion polypeptide comprising the variable region of the light and heavy chain $\left(\mathrm{V}_{\mathrm{L}}, \mathrm{V}_{\mathrm{H}}\right)$; they maintain antigen specificity and can be engineered for intracellular expression or secretion. So far, several groups have investigated the use of $\mathrm{scFv}$ in prion-infected cell culture systems. One group showed the paracrine inhibition of prion replication by RD-4 cells expressing and secreting scFv $(6 \mathrm{H} 4)$ on co-cultured $\mathrm{ScN} 2 \mathrm{a}$ [23]. Another interesting study showed the retention of $\operatorname{PrP}^{\mathrm{C}}$ in the endoplasmic reticulum (ER) of HEK 293 and PC12 cells after the expression of a scFv from antibody $8 \mathrm{H} 4$ and $8 \mathrm{F9}$, containing the ER retention sequence KDEL [24]. Starting from these results a subsequent set of in vivo analyses was carried out showing that mice intracerebrally injected with KDEL-8H4-NGF-differentiated PC12 cells infected with scrapie did not develop scrapie clinical signs or show any brain damage [25]. Moreover, also scFvs directed against the $37 / 67 \mathrm{kDa}$ laminin receptor (LRP/LR) have been recently used as therapeutic approach in prion diseases. Delivery of these scFv both by passive immunotransfer [26] or by adeno-associated virus (AAV)-mediated gene transfer [27] resulted in significant reduction of the peripheral $\mathrm{PrP}^{\mathrm{Sc}}$ propagation. Therefore, these data support the use of $\mathrm{scFv}$ as a therapeutic approach.

Additional support to the potential therapeutic value of intracerebral antibody production has recently been given by two studies showing that brain delivery of either prion-specific scFv by AAV transfer [28] or of a soluble prion antagonist (PrP$\mathrm{FC}_{2}$ ) by lentivirus transfer [29] delay the onset of the disease in infected mice, although protection in these studies was not complete. Because infectious prion replication occurs peripherally within the lymphoreticular system organs, the incomplete protection given by gene transferring of anti-prion molecules in the brain may be consequent to the fact that the peripheral pool of $\operatorname{PrP}^{\mathrm{Sc}}$ continues to replicate and then migrate to the CNS by neuroinvasion [28].

In order to develop a system that could have therapeutic and not only prophylactic 
utility, in this study we combined active and passive immunotherapeutic approaches. First, we have produced a monovalent version of the anti-prion D18Fab, D18scFv, and we have tested it in prion-infected cells. The big improvement of our strategy compared to the previous gene transferring is that our molecule might have effects both peripherically and into the brain. We show here that this recombinant anti-prion $\mathrm{scFv}$ is able to reduce proteinase $\mathrm{K}(\mathrm{PK})$-resistant $\operatorname{PrP}$ accumulation in different infected cell models of prion diseases. Furthermore, in order to provide a localized supply of D18scFv (that could obviate the needs of repetitive injection into the brain), we evaluated and compared the in vitro efficiency of two virus-mediated gene transfer systems. We produced two viral vectors, one based on recombinant AAV serotype 2 (AAV2) and the other on HIV-1, carrying the D18scFv gene and showed that the latter is more efficient in reducing prion levels in cultured infected cells in vitro. These results provide additional support to use small antibody fragments for active and passive immunotherapy in prion diseases and encourage the in vivo evaluation of an anti-prion $\mathrm{scFv}$-based treatment for the therapy of prion disorders. 


\section{EXPERIMENTAL}

\section{Vector production and protein expression and purification}

The D18scFv sequence was assembled by fusion PCR of the $\mathrm{V}_{\mathrm{L}}$ and $\mathrm{V}_{\mathrm{H}}$ of the D18Fab by inserting a 20-amino acid (AA) linker. The resulting sequence was cloned into a pET22b(+) vector (Novagen) digested by BamHI and NotI in order to maintain the pelB leader in the N-terminal and the 6-his tag in the C-terminal part. X11-blue (Stratagene) and B121(DE3) E.coli (Stratagene) were transformed both to amplify and to express the D18scFv, respectively.

For protein expression, transformed BL21(DE3) were scooped into LB broth (Ampicillin $100 \mu \mathrm{g} / \mathrm{ml}$ ) and grown overnight at $37^{\circ} \mathrm{C}$. The overnight culture was diluted 1:50 and grown at $37^{\circ} \mathrm{C}$ up to $\mathrm{OD}_{600}=0.6$, before induction with $0.5 \mathrm{mM}$ isopropyl-beta-thio-galactoside (IPTG) for 3 hours at $37^{\circ} \mathrm{C}$ or overnight at $30^{\circ} \mathrm{C}$.

Bacteria aliquots $(1 \mathrm{ml})$ were centrifuged and analysed for total protein expression by SDS-PAGE on $12 \%$ acrylamide gels and either Coomassie staining and Western blot by using 1:50 HisProbe-HRP (PIERCE Biotechnology, Inc. Rockford, IL)

To test the recovery of $\mathrm{D} 18 \mathrm{scFv}$ from periplasm, bacteria were submitted to osmotic shock with $5 \mathrm{mM} \mathrm{MgSO}{ }_{4}$ at $4^{\circ} \mathrm{C}$ in order to allow the release of periplasmic proteins in the aqueous phase. For cytosolic fraction preparation, bacteria pellet was resuspended in BugBuster Master Mix (Novagen) by pipetting and vortexing and then incubated on a shaking platform for 10-20 $\mathrm{min}$ at room temperature, pelleted, resuspended in BugBuster Master Mix and shaken again twice. Aliquots of pellets and supernatants were analysed by SDS-PAGE followed by either Coomassie staining and Western blot, in order to analyse insoluble and soluble cytosolic fractions. The last pellet was resuspended three times in 1:10 diluted BugBuster Master Mix $(2.5 \mathrm{ml} / \mathrm{gr}$ of the original weight) and centrifuged at $4^{\circ} \mathrm{C}$ twice at $5.000 \mathrm{xg}$ and finally at $16.000 x g$. Since protein was found insoluble, it was purified by IMAC in denaturing conditions and then refolded by fast dilution. Briefly, pellet was resuspended in $10 \mathrm{ml}$ (for a 1-L culture) of denaturing buffer A (6M Gdn- $\mathrm{HCl}, 0,1 \mathrm{M}$ sodium phosphate buffer, 0,01 M Tris-HCl pH 8) and incubated with of 1X Ni-NTA His-bound resin (Novagen) (1 ml/4 $\mathrm{ml}$ of denatured protein) by gently shaking 3-4 hours at room temperature. After incubation, protein-bound resin was washed twice with buffer B (8M Urea, 0,1 M sodium phosphate buffer, 0,01 M Tris- $\mathrm{HCl} \mathrm{pH} \mathrm{6,3)} \mathrm{and} \mathrm{then} \mathrm{the}$ D18scFv was eluted with $4 \times 1 \mathrm{ml}$ buffer $\mathrm{C}$ (8M Urea, $0,1 \mathrm{M}$ sodium phosphate buffer, $0,01 \mathrm{M}$ Tris- $\mathrm{HCl} \mathrm{pH} 5.9$ ), followed by 4 x $1 \mathrm{ml}$ buffer D (8M Urea, $0,1 \mathrm{M}$ sodium phosphate buffer, $0,01 \mathrm{M}$ Tris- $\mathrm{HCl} \mathrm{pH} 4.5$ ). Aliquots of sample were taken at each step for analysis by SDS-PAGE followed by either Coomassie staining and Western blot by using 1:50 HisProbe-HRP. Fractions containing the D18scFv were pulled and diluted about 35 times in $25 \mathrm{mM}$ Tris- $\mathrm{HCl} \mathrm{pH} 8.0,5 \mathrm{mM}$ EDTA for fast refolding. The purified protein was dialysed against $20 \mathrm{mM}$ Tris- $\mathrm{HCl}$ at different $\mathrm{pH}$ (pH 6,$5 ; 7,5$ and 8.5 ) at $4^{\circ} \mathrm{C}$ overnight and then quantified and concentrated. Solubility of the refolded protein was tested by 1 hour of cold ultracentrifugation at $100,000 \times g$ in Beckman Optima MAX ultracentrifuge (MLA-130 rotor) (Beckman Coulter Inc., Palo Alto, CA) before/after concentration.

Activity assays

ELISA: D18scFv was tested for binding to recombinant PrP-Fc.

Plates were coated with $20 \mu \mathrm{g} / \mathrm{ml}$ of goat $\alpha$-human $\mathrm{Fc}$ in $0,1 \mathrm{M} \mathrm{NaHCO}_{3}, \mathrm{pH} 8.6$ overnight at room temperature, washed three times with TBST (20 mM TRIS, 137 $\mathrm{mM} \mathrm{NaCl}, 0,05 \%$ Tween 20, pH 7.5) and then incubated with PBS 0,25\% BSA, $0,05 \%$ Tween 20 for 1 hour at room temperature. PrP-Fc supernatant (containing 1-10 $\mu \mathrm{g} / \mathrm{ml}$ of protein) [30] was pre-incubated with several amounts of D18scFv $(0,05 \mathrm{up}$ 
to $10 \mu \mathrm{g} /$ well) for $15 \mathrm{~min}$ at room temperature and this solution was then incubated with the goat $\alpha$-human Fc present in the wells for 2 hours at room temperature. After washing with TBST and incubation with 1:50 HisProbe-HRP for 1 hour at room temperature, plates were developed with TMB solution (Pierce) for $15 \mathrm{~min}$ and $2 \mathrm{M}$ $\mathrm{H}_{2} \mathrm{SO}_{4}$ and optical density was measured at $450 \mathrm{~nm}$. Several concentrations of $\mathrm{D} 18 \mathrm{Fab}$ were tested as controls.

Western blot competition assay: Aliquots of $5 \mu 110 \%$ brain homogenate from FVB mice were loaded on 12,5\% acrylamide gels and subjected to SDS-PAGE and Western blot. Membranes were saturated with 5\% milk/TBST and incubated for 1 hour with several concentration of D18scFv $(0,05$ up to $2,5 \mu \mathrm{g} / \mathrm{ml})$ together with D18Fab by utilising Fab/scFv ratio of $1: 1 ; 1: 10 ; 1: 50$ and $1: 100$ and then with a goat a-human IgG-F(ab') $)_{2}$-HRP.

\section{Adeno-associated Virus 2 production}

The D18scFv fragment, including the C-terminal 6-his tag and the N-terminal secretion signal, was cloned into the AAV backbone of the plasmid pAAV-MCS (Stratagene) to obtain pAAV- D18scFv.

Infectious AAV2 vector particles were generated by the AAV Vector Unit (AVU) at ICGEB Trieste (http://www.icgeb.org/RESEARCH/TS/COREFACILITIES/AVU.htm) in HEK293 cells, using dual plasmid cotransfection procedure with pDG as packaging helper plasmid (kindly provided by J. A. Kleinschmidt, DKFZ, Germany), as previously described [31]. AAV-D18scFv vector stocks were purified by cesium chloride centrifugation and titration of viral particles was performed by real-time PCR quantification of the number of viral genomes, as described previously [31]; the viral preparations used in this work had titers between $1 \times 10^{11}$ and $1 \times 10^{12}$ viral genome particles (vgp) per ml.

\section{Lentivirus production}

D18scFv cDNA was cloned into the lentiviral vector pRRL.sin.cPPT.hCMV.GFP.Wpre in place of GFP by digestion with AgeI and SalI. Signal peptide from $\mathrm{PrP}^{\mathrm{C}}$ sequence was inserted at the N-terminal (BclI/AgeI). Vectors stocks were generated by cotransfection of $293 \mathrm{~T}$ with pCMV-\{Delta\}R8.91,13 pMD.G,13 and pRRL.sin.cPPT.hCMV.D18scFv vectors. 293T-conditioned media were filtered and ultracentrifuged to concentrate the vector. Particle content was measured by HIV-1 p24 antigen immunocapture. HIV-1 p24 concentration was about $70 \mathrm{ng} / \mathrm{ml}$ (corresponding to 100,000 infectious units per ng of $\mathrm{p} 24$ ).

\section{Cell cultures}

$\mathrm{ScN} 2 \mathrm{a}$ cells and mouse gonadotropin-releasing hormone (GnRH) neuronal cells (ScGT1-1) were maintained in DMEM, $10 \%$ fetal bovine serum (FBS) in a humidified $37^{\circ} \mathrm{C}$ incubator with $5 \% \mathrm{CO}_{2}$.

\section{Studies of D18scFv inhibition}

Several concentrations $(0,1$ up to $5 \mu \mathrm{g} / \mathrm{ml})$ of D18scFv were added to ScGT1-1 cells and incubated for 1 week. The cells were fed three times per week with replacement media containing the appropriate amount of scFv. Cells were collected by washing three times with calcium- and magnesium-free PBS and resuspended in $500 \mu 1$ lysis

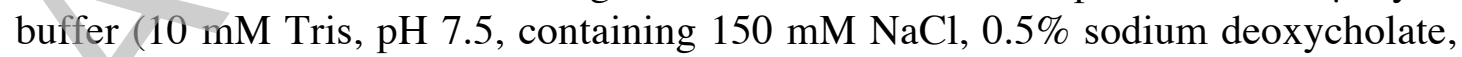
$0.5 \%$ nonident $\mathrm{P}-40$ ). Cell nuclei were removed from the lysate by centrifugation at $2,000 \mathrm{xg}$ for $2 \mathrm{~min}$, and the protein concentration of the supernatant measured by Bradford assay (Pierce) and subjected to PK-resistance assay.

\section{Studies of D18scFv-virus inhibition}

Different titers of lentivirus $\left(10 \times 10^{4}\right.$ up to $\left.10 \times 10^{6} \mathrm{TU}\right)$ and rAAV2 $\left(10 \times 10^{10}\right.$ up to $\left.10 \times 10^{12} \mathrm{TU}\right)$ carrying D18scFv gene were used to infect both ScGT1-1 and ScN2a 
cells. For AAV2 infection, cells were pre-treated with $1 \mathrm{mM}$ idrossiurea for about 16 hours. One week post-infection, cells were collected, resuspended in $500 \mu$ lysis buffer and subjected to PK-resistance assay as described below.

\section{Proteinase K (PK) resistance assay}

ScN2a and ScGT1 cell lysates $(500 \mu \mathrm{g})$ were treated with $20 \mu \mathrm{g} / \mathrm{ml}$ of PK (total protein:enzyme ratio $=50: 1$ ) for $30 \mathrm{~min}$ at $37^{\circ} \mathrm{C}$. Proteolytic digestion was terminated by the addition of phenylmethyl sulphonyl fluoride (PMSF) to a final concentration of $2 \mathrm{mM}$. PK-resistant material was pelleted by centrifugation at $18,000 \mathrm{xg}$ for 1 hour and then resuspended in reducing SDS sample buffer, boiled for $5 \mathrm{~min}$, cleared by centrifugation and resolved by SDS-PAGE (12\%). Samples were transferred on nitrocellulose membrane and blocked with $5 \%$ milk in TBST. Prion protein was detected using SAF61 antibody. Blots were developed with enhanced chemiluminescence (ECL) reagent (Amersham) and exposed to ECL Hypermax film (Amersham).

\section{Bioinformatic models}

The sequence of the D18scFv [32] was compared to the sequences of known 3D structures collected in Protein Data Bank [33] in order to find templates for homology modeling. The anti-prion protein $\mathrm{P}$ scFv fragment (PDB code: $2 \mathrm{HH}$ ) [34] was identified and further used as the template for the modeling. 3D models were built using MODELLER 6v2 [35]. Amino acids of a signal sequence and poly-glycine parts of the sequences were neglected in the modeling. The structure of the D18scFv model was then used to dock the prion protein (PrP; PDB code: 1HJM) [36] by means of the HADDOCK 2.0 program [37, 38]. Residues determined to be important for protein-protein recognition between PrP and D18scFv were reported in the literature [32]. For the purpose of docking, they were filtered according to the solvent accessibility with the NACCESS program. All His residues were deprotonated. Cluster analysis were then performed with programs available in HADDOCK 2.0 $[37,38]$. 


\section{RESULTS AND DISCUSSION}

It has been recently shown that anti-prion scFvs could be delivered to the central nervous system (CNS) of mice by AAV and are able to delay the onset of the disease when used in prophylaxis but not when used after prion-exposure [28]. Contribution to the incomplete protection could derive from down-regulation of the $\mathrm{scFv}$ expression by $\mathrm{PrP}^{\mathrm{Sc}}$ neuroinvasion. In addition, because infectious prions replicate peripherally within the lymphoreticular system organs, the incomplete protection may be consequent to the fact that the peripheral pool of $\mathrm{PrP}^{\mathrm{Sc}}$ continues to replicate and migrate to the CNS by neuroinvasion. These observations make inefficient anti-prion treatments based exclusively on active immunotherapy. Since it has been shown that small proteins can be rapidly delivered and spread in the brain after i.c. injection or after nasal administration [39, 40], we have evaluated, in cell culture, an alternative approach to treat TSEs based on passive immunotherapy.

To this aim, we have produced a smaller version of the D18Fab, the D18scFv in which the variable regions of the light and heavy chains of Fab were fused together by PCR, by inserting a 20-AA linker and adding a 6-histine tag in the C-terminal part (Figure 1). The sequence corresponding to the scFv (Figure 1A) was cloned in a bacterial expression system (Figure 1B) and its expression was induced by using 0.5 $\mathrm{mM}$ IPTG at 30 or $37^{\circ} \mathrm{C}$. A higher expression of the molecule was found at $37^{\circ} \mathrm{C}$, as shown in Figure 2A. To test the recovery of D18scFv from periplasm or cytosol, bacteria were submitted to osmotic shock and treated with $5 \mathrm{mM} \mathrm{MgSO}_{4}$ at $4{ }^{\circ} \mathrm{C}$ in order to allow the release of periplasmic proteins in the aqueous phase recovered after a following step of centrifugation (Figure 2B). For cytosolic fraction preparation, bacteria were resuspended in lysis buffer and after shaking, centrifugation was performed to separate a soluble from an insoluble protein fraction (Figure 2B). Equivalent aliquots of different fractions were analysed by Coomassie staining and Western blot (Figure 2B). Since the larger amount of D18scFv was recovered in the insoluble cytosolic fraction, it was purified by IMAC in denaturing conditions. In all recovered fractions, D18scFv was shown to be highly homogeneous and in considerable amounts (Figure 2C) and therefore refolded by fast-dilution. In order to test for functional refolding after fast dilution at different $\mathrm{pH}(6.5 ; 7.5$ and 8.5) $\mathrm{D} 18 \mathrm{scFv}$ was analysed for its solubility by ultracentrifugation at $100,000 \mathrm{xg}$ (Figure 2D). We found that D18scFv is more soluble at $\mathrm{pH} 8.5$, suggesting that, at this $\mathrm{pH}$, it has lower tendency to precipitate and aggregate and therefore its conformation is more stable.

In order to directly test for interaction and anti-prion activity, D18scFv was evaluated for its binding to $\operatorname{PrP}$. Specifically, we tested the ability of this molecule to bind recombinant PrP-Fc [30] in an ELISA assay and no significant differences was found for the different $\mathrm{pH}$ refolding conditions (Figure 3A, right graph). Promisingly, $\mathrm{D} 18 \mathrm{scFv}$ was found to maintain the same affinity for PrP of the original D18Fab used as control (Figure 3A, left graph). We also tested the ability of the scFv to bind $\operatorname{PrP}^{\mathrm{C}}$ present in brain homogenate from FVB mice. We set up a competition assay between the D18scFv and the D18Fab, which could be detected in western blot by an antihuman $\left(\mathrm{Fab}^{\prime}\right)_{2}$-HRP (Figure 3B). The reduction of PrP signal by utilising a Fab/scFv ratio of $1: 50$ and $1: 100$ clearly showed the ability of the $\mathrm{scFv}$ to specifically interact with PrP and to compete with the Fab for its binding. Moreover, we did not find any difference among the $\mathrm{scFv}$ refolded at the different $\mathrm{pH}$ (data not shown).

Due to the interest on how D18scFv interacts with the $\mathrm{PrP}^{\mathrm{C}}$, we have used bioinformatic approaches to construct a structural model of $\mathrm{D} 18 \mathrm{scFv}-\mathrm{PrP}^{\mathrm{C}}$ complex. This kind of approach is commonly used as a first attempt to identify $3 \mathrm{D}$ structures of 
the proteins and protein-protein interactions in the absence of detailed experimental data. Firstly, the 3D structure of D18scFv was modeled based on anti-prion protein $\mathrm{P}$ scFv fragment (PDB code: 2HH0) [34]. This fragment was crystallized in a complex with a small peptide. Due to the presence of a small peptide, the complementarity determining regions 3 (CDR3) are farther apart than in non-complexed antibody structures. Therefore, this structure was taken as a template for the model of the $\mathrm{D} 18 \mathrm{scFv}$ since it allows an easy approach of the $\operatorname{PrP}^{\mathrm{C}}$ to the cavity of the antibody in the docking procedure (Figure $4 \mathrm{~A}$ ). Then a D18scFv-PrP ${ }^{\mathrm{C}}$ complex was built by docking of $\mathrm{PrP}^{\mathrm{C}}$ (PDB code: 1HJM) [36] to the model of D18scFv. According to the docking results, $\operatorname{Arg}_{\mathrm{PrP}} 151$ ( $\mathrm{Arg} 151$ from $\mathrm{PrP}$ ) is the key residue for the interactions with D18scFv. It anchors the $\operatorname{PrP}^{\mathrm{C}}$ to the cavity of the antibody forming H-bonds with $\operatorname{Tyr}_{\mathrm{VH}} 32$ (Tyr32 in heavy variable chain), $\operatorname{Asn}_{\mathrm{VH}} 33, \operatorname{Asp}_{\mathrm{VH}} 35$ and $\mathrm{Tyr}_{\mathrm{VL}} 210$ (Tyr210 in light variable chain), along with van der Waals interactions with $\operatorname{Trp}_{\mathrm{VL}} 205$ (Figure 4B). A series of other H-bonds and hydrophobic interactions contribute further to the $\mathrm{D} 18 \mathrm{scFv}-\mathrm{PrP}^{\mathrm{C}}$ complex stability.

Due to the lack of available mutational data it is difficult to evaluate accurately our models. However, the modeled structure of D18scFv-PrP ${ }^{\mathrm{C}}$ complex might provide an insight to the relevant interactions between the two proteins and give new suggestions for mutational studies.

The next step was to test $\mathrm{D} 18 \mathrm{scFv}$ for its effect on scrapie replication in scrapie infected cell lines (Figure 5). After incubation of ScGT1 cells with different concentrations $(0.1 ; 0.5 ; 1$ and $5 \mu \mathrm{g} / \mathrm{ml})$ of $\mathrm{scFv}$ for 1 week, $\mathrm{scFv}$ was found to reduce PK-resistant PrP levels in a concentration-dependent manner, similarly to what was found for the Fab in ScN2a cells [12]. In particular, we found $20 \% \pm 4,50 \% \pm 7,80 \% \pm 3$ and $95 \% \pm 1$ PK-resistant PrP reduction by using respectively $0.1,0.5,1$ and $5 \mu \mathrm{g} / \mathrm{ml}$ D18scFv. We have used R2Fab $(10 \mu \mathrm{g} / \mathrm{ml})$ that was shown to be ineffective on reducing PK-resistant PrP in ScN2a cells [12] and D18Fab (1 and $5 \mu \mathrm{g} / \mathrm{ml})$ was used as positive control. Interestingly, the same concentration of Fab and scFv (compare lanes $5 \mu \mathrm{g} / \mathrm{ml}$, respectively) is required to achieve the same extend of reduction in $\mathrm{PrP}^{\mathrm{Sc}}$ level. However, since the $\mathrm{scFv}$ is approximately half molecular weight compared with the Fab, D18scFy is 2-fold less effective than Fab with respect to the reduction of the $\mathrm{PrP}^{\mathrm{Sc}}$ level in ScGT1 cells. After 1 week treatment, PK-resistant $\operatorname{PrP}$ was reduced to undetectable levels but was not completely eliminated from the cells because it reappeared after 1 additional week of growth in the absence of the scFv (data not shown). However, after 2 or 3 weeks of $\mathrm{scFv}$ treatment PK-resistant PrP remained undetectable for up to 3 weeks of culture without adding any scFv (data not shown), as it has been shown for the original Fab [12]. Also in this case we found no difference among the $\mathrm{scFv}$ refolded at the different $\mathrm{pH}$ (Figure 5). These data indicate that the small monovalent antibody fragment might be a very useful tool in therapy because it is able to interfere with prion metabolism (either reducing conversion or promoting degradation) in infected cells. The big improvement of our strategy compared to the previous gene transferring-based approaches [28] is that our molecule might have effects both peripherically and into the brain, both of them sites of prion replication.

In vivo the putative anti-prion effects of the $\mathrm{D} 18 \mathrm{scFv}$ expressed as recombinant protein might be enhanced by combining passive and active immunotherapeutic approaches.

Recently, different gene transfer approaches in anti-prion prophylaxis of infected animals have been successfully used by using either lentivirus carrying a soluble prion antagonist [29] or AAV transducing either anti-LPR/LR [27] or anti-prion protein 
specific scFvs [28]. Therefore, in order to have a continuous supply of our recombinant $\mathrm{scFv}$ to be eventually used in immunotherapy in animals and to test the effectiveness of these two viral systems, we cloned the gene encoding for D18scFv (Figure 1A) either in a defective lentiviral vector (pTTLsin.PPT.hPGK.GFPpre) (Figure 6A, left panel) or in an AAV vector (pAAV-MCS) (Figure 6A, right panel).

The lentivirus vector was transfected in association with a three-plasmid expression system in $293 \mathrm{~T}$ cells in order to produce a functional lentivirus. A lentivirus containing a GFP reporter gene was used to test the efficiency of viral transduction. At 48 hours post-transduction, ScGT1 cells were analysed by immunofluorescence and we found that the $35 \% \pm 5$ of ScGT1 cells were GFP positive (data not shown). Lentivirus carrying the D18scFv was titered and tested for its effectiveness in reducing PK-resistant PrP content in infected cell cultures. Titers of $10 \times 10^{4}$ up to $10 \times 10^{6}$ TU were used to transduce both ScGT1 and ScN2a cells. One week posttransduction D18scFv was expressed (Figure 6B) and the levels of PK-resistant PrP were reduced of $80 \% \pm 7$ and $90 \% \pm 3$ respectively in ScGT1 and ScN2a cells by using the highest viral titer tested $\left(10 \times 10^{6} \mathrm{TU}\right)$ (Figure 6C). Interestingly, the effect on PKresistant PrP content after lentivirus transduction was more pronounced in $\mathrm{ScN} 2 \mathrm{a}$ cells, where even a lower titer of $10 \times 10^{4} \mathrm{TU}$ was effective (Figure 6C). Alternatively, we also produced a recombinant (rec) AAV2 (see Experimental) expressing D18scFv and subsequently packaged into virus stocks for CNS delivery (see Experimental). Titers of $10 \times 10^{10}$ up to $10 \times 10^{12}$ TU were used to transduce both ScGT1 and ScN2a cells and transgene expression (Figure 6B) and PK-resistant PrP levels (Figure 6C) were checked one week post-transduction. Interestingly, only the highest titer tested $\left(10 \times 10^{12} \mathrm{TU}\right)$ was able to reduce PK-resistant PrP level of $20 \% \pm 5$ in ScN2a cells (Figure 6C). Same result is achieved after longer period of viral transduction (up to 3 weeks) (data not shown). Also in this case we used an AVV2-containing GFP to evaluate the efficiency of viral transduction. At 48 hours post-transduction, $15 \% \pm 8$ of ScGT1 cells were GFP positive (data not shown). These data indicate that, at least in cell culture models, lentivirus transduces $\mathrm{D} 18 \mathrm{scFv}$ in a functional form able to prevent or interfere with $\mathrm{PrP}^{\mathrm{Sc}}$ conversion and seem to represent a better delivery system compared to AAV. In comparison, due to the well-known high tropism of rAAVs for brain neurons in yivo, recently supported by its efficacy in different clinical trials for neurodegenerative disorders (see, among others: [41]), AAV-scFv remains a valuable potential tool for the in vivo treatment of prion disease. How these viruses act in reducing PK-resistant PrP levels has to be still elucidated. One possibility could be that anti-PrP scFvs block conversion reaction directly. Alternatively, PK-resistant PrP reduction could be an indirect effect of downregulation of $\operatorname{PrP}^{\mathrm{C}}$ expression. Nevertheless, the eventual regulation of $\operatorname{PrP}^{\mathrm{C}}$ expression is specifically due to the $\mathrm{scFv}$, because viruses expressing other constructs (GFP-PrP) do not reduce PK-resistant PrP content in scGT1 cells (data not shown). In conclusion, we validated here the use of $\mathrm{D} 18 \mathrm{scFv}$ as potential anti-prion immunotherapeutic both as purified protein and after viral transduction in cultured neuronal cells. The availability of our lentiviral and AAV2 vectors expressing the same therapeutic molecule will now allow us to directly compare the efficacy of the two viral vectors in sick animals in vivo. 
ACKNOWLEDGEMENTS: We thank P. Culhane for technical advices in scFv expression and purification. V.C. received a short-term fellowship from the program of International Exchanges between "Federico II" University and others Foreign Research Institutes for Short-term Mobility of Professors, Students and Researchers" of University of Naples "Federico II" to work at UCSF.

This work was supported by grants to C.Z. from the European Union FP6 programme (QLK2-CT-2002-81628 and LSHBCT 2006-019090), from FIRB (2003) and Telethon Foundation (GGP04147) and by grant from Italian Institute of Technology SISSA Unit to G.L. 


\section{FIGURE LEGENDS}

Fig.1: Schema of the D18scFv in pET-22b(+). A) Sequence of the D18scFv. The different regions of the sequence are indicated with different colors: the pelB leader is light gray, the $\mathrm{V}_{\mathrm{H}}$ and $\mathrm{V}_{\mathrm{L}}$ sequences are red, the 20-AA linker is grey and the 6histidine tag is yellow. B) Cloning of the D18scFv in pET-22b(+). The D18 scFv was obtained by PCR ligation of the variable regions of the light [42] and heavy $\left(\mathrm{V}_{\mathrm{H}}\right)$ chains of FabD18, by inserting a 20-AA linker. The sequence corresponding to the $\mathrm{scFv}(\mathrm{A})$ was inserted between BamHI and NotI restriction enzyme sites present in the multiple cloning site of pET-22b(+) expression vector by keeping the pelB leader and the 6-histidine tag already present in the vector.

Fig.2: Expression and purification of the D18scFv. A) Expression of the D18scFv in E. coli. BL21 (DE3) Rosetta-gami E. coli strain was transformed and induced by using $0.5 \mathrm{mM} \mathrm{IPTG} \mathrm{(+)} \mathrm{at} 30$ or $37^{\circ} \mathrm{C}$. Note that a higher expression of the molecule was found at $37^{\circ} \mathrm{C}$. B) Cytoplasmic extraction of the D18scFv. D18scFv was recovered from periplasmic (P) or both soluble (S) and insoluble (I) cytosolic preparations. Equivalent aliquots of the different obtained fractions were analysed by Coomassie staining (top panel) and Western blot by using an anti-6his probe (bottom panel). Note that the larger amount of D18scFv was recovered in the insoluble cytosolic fraction. C) Purification of insoluble D18scFv. Insoluble D18scFv was purified by IMAC after denaturation by using $6 \mathrm{M}$ Guanidium-HCl. After elution, 8 different fractions were collected and analysed by Coomassie staining (top panel) and Western blot by using an anti-6his probe (bottom panel). Note that the scFv shows a high degree of homogeneity and is in consistent amount in all the analysed fractions. B: IPTG-induced bacteria. D) Solubility of the D18scFv after ultracentrifugation. Purified D18scFv refolded at different $\mathrm{pHs}(6,5 ; 7,5$ and 8,5$)$ was ultracentrifuged at $100,000 \mathrm{xg}(+)$ and analysed by Coomassie staining. Note that D18scFv is more soluble at $\mathrm{pH} 8,5$. Arrows indicate D18scFv.

Fig.3: Analysis of activity of the D18scFv. A) D18scFv binding to recombinant PrPFc. ELISA assays were performed to test the binding to recombinant PrP-Fc of D18scFv (left graph) in comparison to FabD18 (right graph). Note that no significant difference was found for the different $\mathrm{pH}$ refolding conditions and that $\mathrm{D} 18 \mathrm{scFv}$ maintains the same affinity for PrP of the original D18Fab. B) D18scFv binding to $\operatorname{PrP}^{\mathrm{C}}$ present in mouse brain homogenate. Western blot competition assay between the D18scFv and the D18Fab was set up as described in Experimental. Different concentrations of D18scFv were tested in competing D18Fab detection of $\operatorname{PrP}^{\mathrm{C}}$. Note that the reduction of PrP signal by utilising a Fab/scFv ratio of 1:50 and 1:100 clearly showed the ability of the scFv to specifically interact with PrP and to compete with the Fab for its binding.

Fig. 4: Model of interaction between D18scFv and PrP. A) Complex between D18scFv (silver) and PrP (blue). Epitope residues of PrP (yellow) interact with the six CDR loops (red - CDR3, green - CDR1,2) of the antibody. B) Arg151 anchors the PrP to the cavity of the antibody through the H-bond and van der Waals interactions with Tyr32, Asn33, Asp35, Trp205 and Tyr210.

Fig. 5: Effect of D18scFv in curing scrapie infected GT1 cells. ScGT1 cells were incubated for 1 week with different concentrations $(0.1 ; 0.5 ; 1$ and $5 \mu \mathrm{g} / \mathrm{ml})$ of scFv refolded at different $\mathrm{pH}(\mathrm{pH} 6.5 ; 7.5$ and 8.5). As controls, $\mathrm{R} 2(10 \mu \mathrm{g} / \mathrm{ml})$ and D18Fab $(1$ and $5 \mu \mathrm{g} / \mathrm{ml})$ were used. $\mathrm{PrP}^{\mathrm{Sc}}$ present in cell lysates was digested with Proteinase $\mathrm{K}(\mathrm{PK}+)$ as described in Experimental and detected by western blot by using SAF61 
antibody. Note that scFv reduces PK-resistant PrP level of $20 \% \pm 4,50 \% \pm 7,80 \% \pm 3$ and $95 \% \pm 1$ by using respectively $0.1,0.5,1$ and $5 \mu \mathrm{g} / \mathrm{ml}$ D18scFv. Blots of PKresistant assays were quantified by ImageJ $(n=3)$ and Student T-test was used to calculate significance of data $(\mathrm{p}<0.05)$. No difference was found among the scFvs refolded at the different $\mathrm{pH}$.

Fig. 6: Production and cellular test of lentivirus and AAV2 containing the D18scFv. A) Cloning of the D18scFv in pTTLsin.PPT.hPGK.GFPpre and in pAAVMCS. For lentiviral vector production (left panel), the gene encoding for D18scFv (Figure 1A) was cloned in defective lentiviral vector (pTTLsin.PPT.hPGK.GFPpre) between AgeI and SalI restriction enzyme sites. The signal peptide of the PrP sequence was cloned upstream between BclI and AgeI. For AAV vector production (right panel), the gene encoding for D18scFv was cloned in pAAV-MCS between HindIII and BglII restriction enzyme sites. For secretion, the signal peptide of the immunoglobulin (Ig) sequence was added between HindIII and ApaLI. B) Expression of D18scFv after transduction of ScGT1 and ScN2a cells. $10 \times 10^{4}$ TU of lentivirus and $10 \times 10^{10} \mathrm{TU}$ of rAAV2 were used to transduce both ScGT1 and ScN2a cells. One week post-infection, D18scFv expression was tested by western blot by using an anti6his tag antibody. C) Effect of the lentivirus and rAAV2 carrying the D18scFv in curing scrapie infected neuronal cell lines. Titers of $10 \times 10^{4}-10 \times 10^{6} \mathrm{TU}$ of the lentivirus (left panels) and $10 \times 10^{10}-10 \times 10^{12} \mathrm{TU}$ of rAAV2 (right panels) carrying the $\mathrm{D} 18 \mathrm{scFv}$ were used to infect both ScGT1 and ScN2a cells. One week post-infection, $\mathrm{PrP}^{\mathrm{Sc}}$ present in cell lysates was digested with proteinase $\mathrm{K}(\mathrm{PK}+)$ as described in Experimental and detected by western blot by using SAF61 antibody. Blots of PKresistant assays were quantified by ImageJ $(n=3)$ and Student T-test was used to calculate significance of data $(\mathrm{p}<0.05)$. By using increasing titer of lentivirus, levels of PK-resistant PrP were reduced of $2 \% \pm 7,75 \% \pm 3$ and $80 \% \pm 7$ in ScGT1 and $76 \% \pm 2$, $80 \% \pm 7$ and $90 \% \pm 3$ in ScN2a cells. By using increasing titer of AAV2, levels of PKresistant PrP were reduced of $2 \% \pm 3,5 \% \pm 3$ and $5 \% \pm 4$ in ScGT1 and 4\% $\pm 2,4 \% \pm 7$ and $20 \% \pm 5$ in ScN2a cells. Note that levels of PK-resistant PrP were significantly reduced in both cell systems by using the highest lentiviral titer tested $\left(10 \times 10^{6} \mathrm{TU}\right)$. 


\section{REFERENCES}

1 Prusiner, S. B. (1998) Prions. Proc Natl Acad Sci U S A. 95, 13363-13383.

2 Will, R. G., Ironside, J. W., Zeidler, M., Cousens, S. N., Estibeiro, K., Alperovitch, A., Poser, S., Pocchiari, M., Hofman, A. and Smith, P. G. (1996) A new variant of Creutzfeldt-Jakob disease in the UK. Lancet. 347, 921-925

3 Horiuchi, M. and Caughey, B. (1999) Specific binding of normal prion protein to the scrapie form via a localized domain initiates its conversion to the proteaseresistant state. Embo J. 18, 3193-3203.

4 Bueler, H., Aguzzi, A., Sailer, A., Greiner, R. A., Autenried, P., Aguet, M. and Weissmann, C. (1993) Mice devoid of PrP are resistant to scrapie. Cell. 73, 13391347.

5 Richt, J. A., Kasinathan, P., Hamir, A. N., Castilla, J., Sathiyaseelan, T., Vargas, F., Sathiyaseelan, J., Wu, H., Matsushita, H., Koster, J., Kato, S., Ishida, I., Soto, C., Robl, J. M. and Kuroiwa, Y. (2007) Production of cattle lacking prion protein. Nat Biotechnol. 25, 132-138

6 Brandner, S., Isenmann, S., Raeber, A., Fischer, M., Sailer, A., Kobayashi, Y., Marino, S., Weissmann, C. and Aguzzi, A. (1996) Normal host prion protein necessary for scrapie-induced neurotoxicity. Nature. 379, 339-343.

7 Weissmann, C. and Aguzzi, A. (2005) Approaches to therapy of prion diseases. Annu Rev Med. 56, 321-344

8 Ludewigs, H., Zuber, C., Vana, K., Nikles, D., Zerr, I. and Weiss, S. (2007) Therapeutic approaches for prion disorders. Expert Rev Anti Infect Ther. 5, 613-630

9 Trevitt, C. R. and Collinge, J. (2006) A systematic review of prion therapeutics in experimental models. Brain. 129, 2241-2265

10 Crozet, C., Lin, Y. L., Mettling, C, Mourton-Gilles, C., Corbeau, P., Lehmann, S. and Perrier, V. (2004) Inhibition of PrPSc formation by lentiviral gene transfer of PrP containing dominant negative mutations. J Cell Sci. 117, 5591-5597

11 Pfeifer, A., Eigenbrod, S., Al-Khadra, S., Hofmann, A., Mitteregger, G., Moser, M., Bertsch, U. and Kretzschmar, H. (2006) Lentivector-mediated RNAi efficiently suppresses prion protein and prolongs survival of scrapie-infected mice. $\mathbf{J}$ Clin Invest. 116, 3204-3210

12 Peretz, D., Williamson, R. A., Kaneko, K., Vergara, J., Leclerc, E., SchmittUlms, G., Mehlhorn, I. R., Legname, G., Wormald, M. R., Rudd, P. M., Dwek, R. A., Burton, D. R. and Prusiner, S. B. (2001) Antibodies inhibit prion propagation and clear cell cultures of prion infectivity. Nature. 412, 739-743.

13 Heppner, F. L. and Aguzzi, A. (2004) Recent developments in prion immunotherapy. Curr Opin Immunol. 16, 594-598

14 Enari, M., Flechsig, E. and Weissmann, C. (2001) Scrapie prion protein accumulation by scrapie-infected neuroblastoma cells abrogated by exposure to a prion protein antibody. Proc Natl Acad Sci U S A. 98, 9295-9299.

15 Sigurdsson, E. M., Sy, M. S., Li, R., Scholtzova, H., Kascsak, R. J., Kascsak, R., Carp, R., Meeker, H. C., Frangione, B. and Wisniewski, T. (2003) Anti-prion antibodies for prophylaxis following prion exposure in mice. Neurosci Lett. 336, 185187

16 Gabizon, R., McKinley, M. P., Groth, D. and Prusiner, S. B. (1988) Immunoaffinity purification and neutralization of scrapie prion infectivity. Proc Natl Acad Sci U S A. 85, 6617-6621 
17 Souan, L., Tal, Y., Felling, Y., Cohen, I. R., Taraboulos, A. and Mor, F. (2001) Modulation of proteinase-K resistant prion protein by prion peptide immunization. Eur J Immunol. 31, 2338-2346

18 White, A. R., Enever, P., Tayebi, M., Mushens, R., Linehan, J., Brandner, S., Anstee, D., Collinge, J. and Hawke, S. (2003) Monoclonal antibodies inhibit prion replication and delay the development of prion disease. Nature. 422, 80-83

19 Polymenidou, M., Heppner, F. L., Pellicioli, E. C., Urich, E., Miele, G., Braun, N., Wopfner, F., Schatzl, H. M., Becher, B. and Aguzzi, A. (2004) Humoral immune response to native eukaryotic prion protein correlates with anti-prion protection. Proc Natl Acad Sci U S A. 101 Suppl 2, 14670-14676

20 Solforosi, L., Criado, J. R., McGavern, D. B., Wirz, S., Sanchez-Alavez, M., Sugama, S., DeGiorgio, L. A., Volpe, B. T., Wiseman, E., Abalos, G., Masliah, E., Gilden, D., Oldstone, M. B., Conti, B. and Williamson, R. A. (2004) Cross-linking cellular prion protein triggers neuronal apoptosis in vivo. Science. 303, 1514-1516

21 Chekhonin, V. P., Ryabukhin, I. A., Zhirkov, Y. A., Kashparov, I. A. and Dmitriyeva, T. B. (1995) Transport of hydrophobized fragments of antibodies through the blood-brain barrier. Neuroreport. 7, 129-132

22 Girod, J., Fenart, L., Regina, A., Dehouck, M. P., Hong, G., Scherrmann, J. M., Cecchelli, R. and Roux, F. (1999) Transport of cationized anti-tetanus Fab'2 fragments across an in vitro blood-brain barrier model: involvement of the transcytosis pathway. J Neurochem. 73, 2002-2008

23 Donofrio, G., Heppner, F. L., Polymenidou, M., Musahl, C. and Aguzzi, A. (2005) Paracrine inhibition of prion propagation by anti-PrP single-chain Fv miniantibodies. J Virol. 79, 8330-8338

24 Cardinale, A., Filesi, I., Vetrugno, V., Pocchiari, M., Sy, M. S. and Biocca, S. (2005) Trapping prion protein in the endoplasmic reticulum impairs PrPC maturation and prevents PrPSc accumulation. J Biol Chem. 280, 685-694

25 Vetrugno, V., Cardinale, A., Filesi, I., Mattei, S., Sy, M. S., Pocchiari, M. and Biocca, S. (2005) KDEL-tagged anti-prion intrabodies impair PrP lysosomal degradation and inhibit scrapie infectivity. Biochem Biophys Res Commun. 338, 1791-1797

26 Zuber, C., Knackmuss, S., Rey, C., Reusch, U., Rottgen, P., Frohlich, T., Arnold, G. J., Pace, C., Mitteregger, G., Kretzschmar, H. A., Little, M. and Weiss, S. (2008) Single chain Fv antibodies directed against the $37 \mathrm{kDa} / 67 \mathrm{kDa}$ laminin receptor as therapeutic tools in prion diseases. Mol Immunol. 45, 144-151

27 Zuber, C., Mitteregger, G., Schuhmann, N., Rey, C., Knackmuss, S., Rupprecht, W., Reusch, U., Pace, C., Little, M., Kretzschmar, H. A., Hallek, M., Buning, H. and Weiss, S. (2008) Delivery of single-chain antibodies (scFvs) directed against the $37 / 67 \mathrm{kDa}$ laminin receptor into mice via recombinant adeno-associated viral vectors for prion disease gene therapy. J Gen Virol. 89, 2055-2061

28 Wuertzer, C. A., Sullivan, M. A., Qiu, X. and Federoff, H. J. (2008) CNS delivery of vectored prion-specific single-chain antibodies delays disease onset. Mol Ther. 16, 481-486

29 Genoud, N., Ott, D., Braun, N., Prinz, M., Schwarz, P., Suter, U., Trono, D. and Aguzzi, A. (2008) Antiprion prophylaxis by gene transfer of a soluble prion antagonist. Am J Pathol. 172, 1287-1296

30 Legname, G., Nelken, P., Guan, Z., Kanyo, Z. F., DeArmond, S. J. and Prusiner, S. B. (2002) Prion and doppel proteins bind to granule cells of the cerebellum. Proc Natl Acad Sci U S A. 99, 16285-16290 
31 Zentilin, L., Marcello, A. and Giacca, M. (2001) Involvement of cellular double-stranded DNA break binding proteins in processing of the recombinant adenoassociated virus genome. J Virol. 75, 12279-12287

32 Williamson, R. A., Peretz, D., Pinilla, C., Ball, H., Bastidas, R. B., Rozenshteyn, R., Houghten, R. A., Prusiner, S. B. and Burton, D. R. (1998) Mapping the prion protein using recombinant antibodies. J Virol. 72, 9413-9418

33 Berman, H. M., Westbrook, J., Feng, Z., Gilliland, G., Bhat, T. N., Weissig, H., Shindyalov, I. N. and Bourne, P. E. (2000) The Protein Data Bank. Nucleic Acids Res. 28, 235-242

34 Luginbuhl, B., Kanyo, Z., Jones, R. M., Fletterick, R. J., Prusiner, S. B., Cohen, F. E., Williamson, R. A., Burton, D. R. and Pluckthun, A. (2006) Directed evolution of an anti-prion protein $\mathrm{scFv}$ fragment to an affinity of $1 \mathrm{pM}$ and its structural interpretation. J Mol Biol. 363, 75-97

35 Sali, A. and Blundell, T. L. (1993) Comparative protein modelling by satisfaction of spatial restraints. J Mol Biol. 234, 779-815

36 Calzolai, L. and Zahn, R. (2003) Influence of $\mathrm{pH}$ on NMR structure and stability of the human prion protein globular domain. J Biol Chem. 278, 35592-35596

37 de Vries, S. J., van Dijk, A. D., Krzeminski, M., van Dijk, M., Thureau, A., Hsu, V., Wassenaar, T. and Bonvin, A. M. (2007) HADDOCK versus HADDOCK: new features and performance of HADDOCK2.0 on the CAPRI targets. Proteins. 69, 726-733

38 Dominguez, C., Boelens, R. and Bonvin, A. M. (2003) HADDOCK: a proteinprotein docking approach based on biochemical or biophysical information. J Am Chem Soc. 125, 1731-1737

39 Ross, T. M., Martinez, P. M., Renner, J. C., Thorne, R. G., Hanson, L. R. and Frey, W. H., 2nd. (2004) Intranasal administration of interferon beta bypasses the blood-brain barrier to target the central nervous system and cervical lymph nodes: a non-invasive treatment strategy for multiple sclerosis. J Neuroimmunol. 151, 66-77

40 Thorne, R. G., Hanson, L. R., Ross, T. M., Tung, D. and Frey, W. H., 2nd. (2008) Delivery of interferon-beta to the monkey nervous system following intranasal administration. Neuroscience. 152, 785-797

41 Kaplitt, M. G., Feigin, A., Tang, C., Fitzsimons, H. L., Mattis, P., Lawlor, P. A., Bland, R. J., Young, D., Strybing, K., Eidelberg, D. and During, M. J. (2007) Safety and tolerability of gene therapy with an adeno-associated virus (AAV) borne GAD gene for Parkinson's disease: an open label, phase I trial. Lancet. 369, 20972105

42 Horonchik, L., Tzaban, S., Ben-Zaken, O., Yedidia, Y., Rouvinski, A., PapyGarcia, D., Barritault, D., Vlodavsky, I. and Taraboulos, A. (2005) Heparan sulfate is a cellular receptor for purified infectious prions. J Biol Chem. 280, 17062-17067 


\section{A}

MKYLLPTAAAGLLLLAAQPAMAMDIGINSDPAYAEVQLLE QSGPELVKPGSSVKISCKASRYTFTDYNMDWVKQSHGKRL EWIGYIYPNTGVTGYNQRFKGKATLTVDKSSSTAYMELRSL TSEDSAVYYCAGFYYGMDYWGQGTSVTVSSASTKGGGGG SGGGGSGGEGSGGGGSATKAYAELVTQSPAFMSASPGEKV TMTCSASSSVNYMHWYQQKSGTSPKRWIYDTSKLASGVPA RFSGSGSGTSYSLTISSMEAEDAATYYCQQWSSNPYTFGGG TKLEIKRT AAALEHHHHHEHH

B
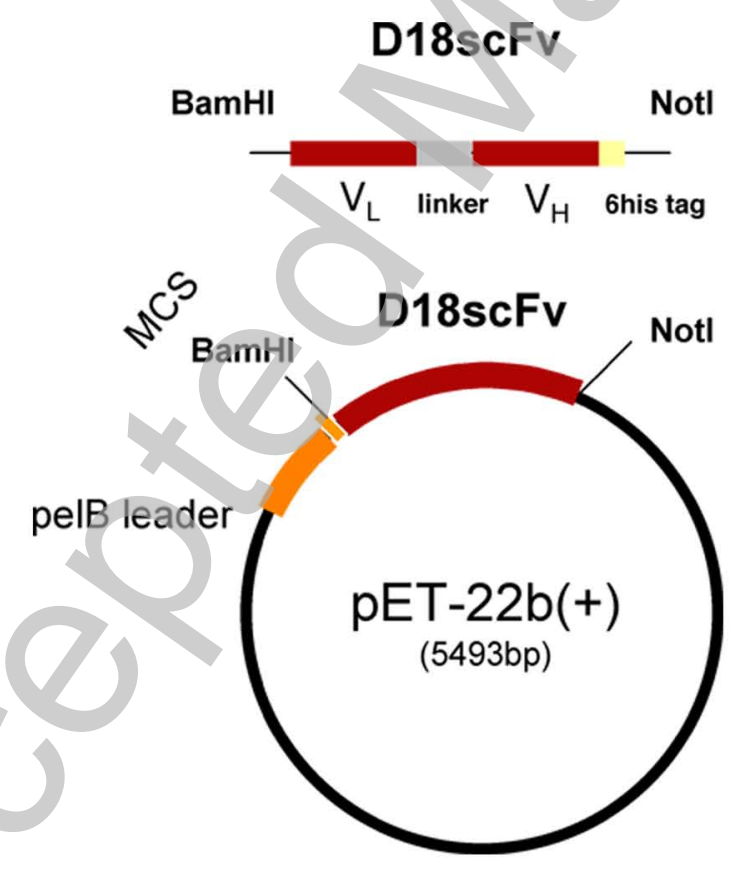

Figure 1 
A

B
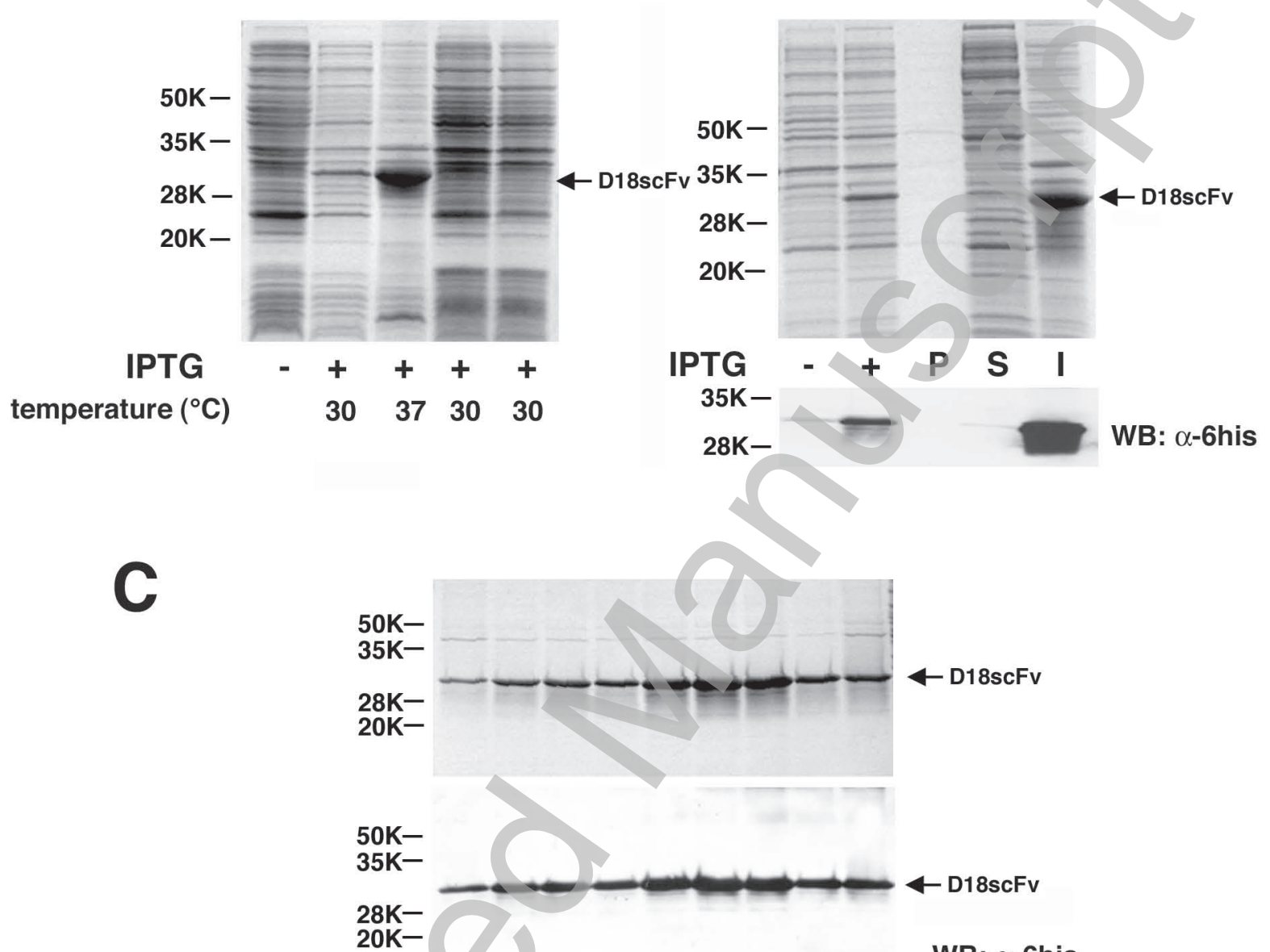

WB: $\alpha-6$ his

$$
\begin{array}{lllllllll}
1 & 2 & 3 & 4 & 5 & 6 & 7 & 8 & \text { B }
\end{array}
$$

D

pH 6,5

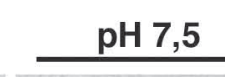

$\mathrm{pH} 7,5$

pH 8,5

$50 \mathrm{~K}-$

$35 \mathrm{~K}-$

$28 \mathrm{~K}-$

20K-

concentration

ultracentrifugation

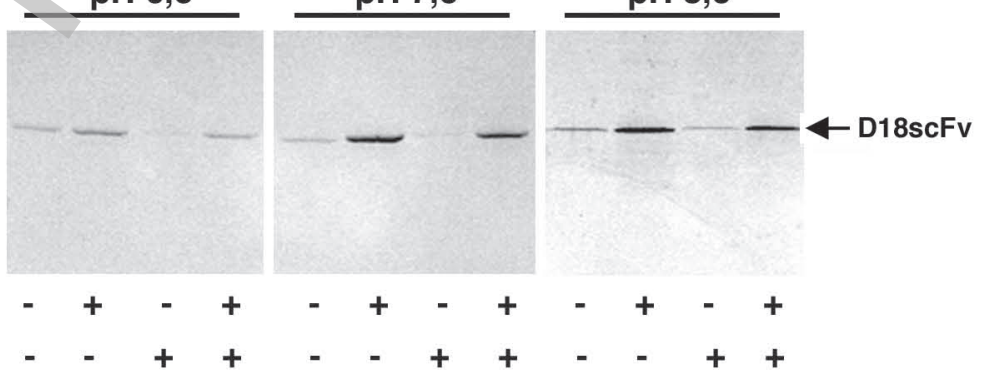

Figure 2 


\section{A}
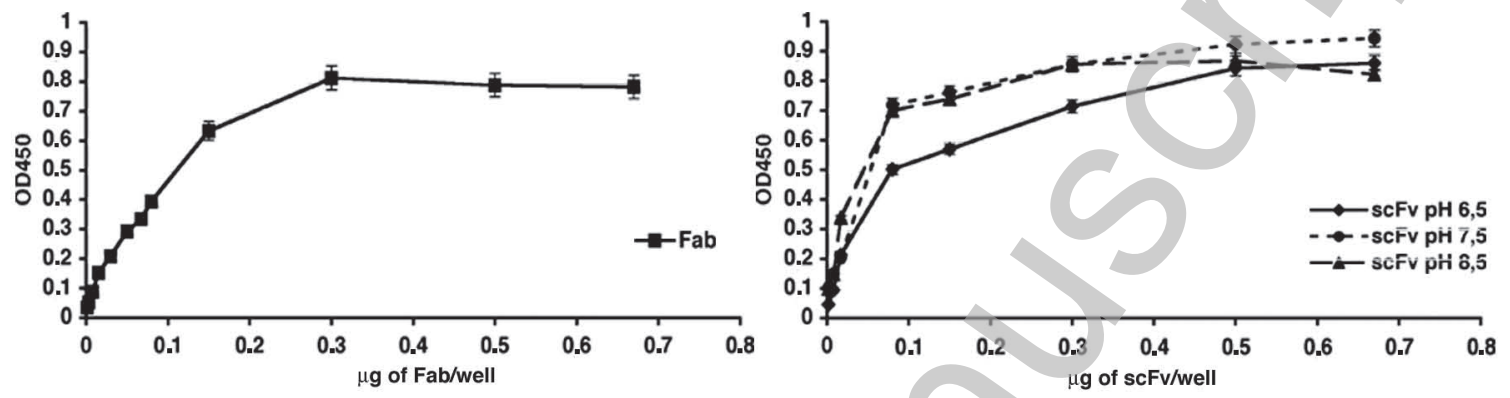

B

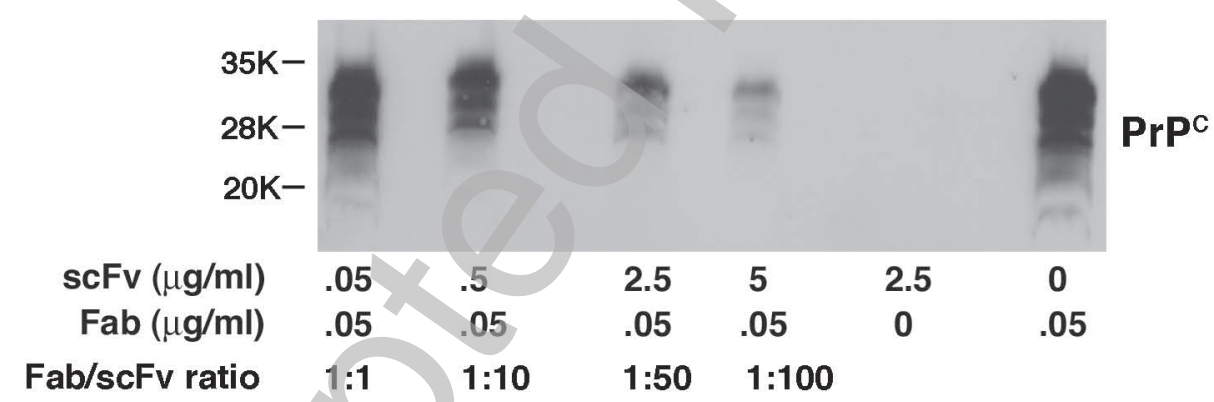

Figure 3

Licenced copy. Copying is not permitted, except with prior permission and as allowed by law. (C) 2008 The Authors Journal compilation (c) 2008 Portland Press Limited 
A

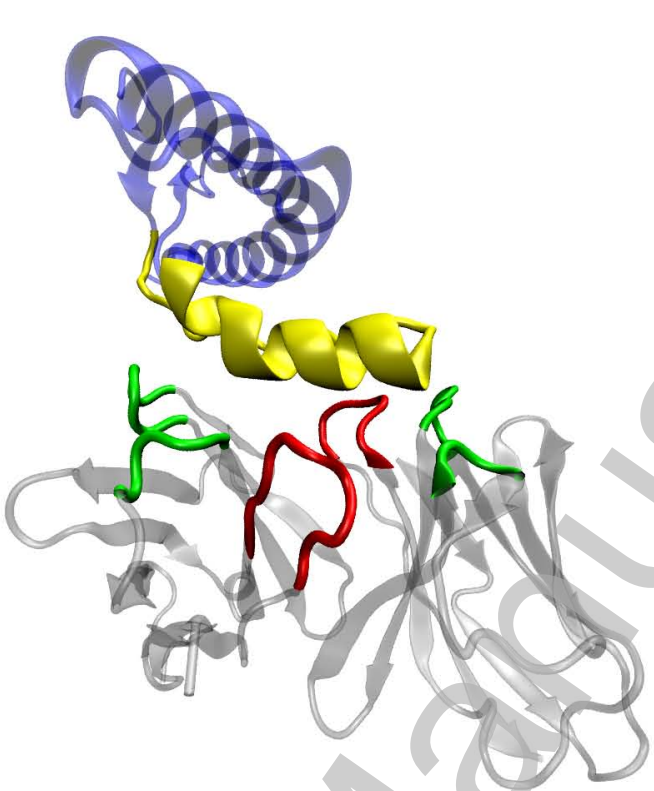

B

Figure 4 
B Biochemical Journal Immediate Publication. Published on 11 Nov 2008 as manuscript BJ20081541 
A
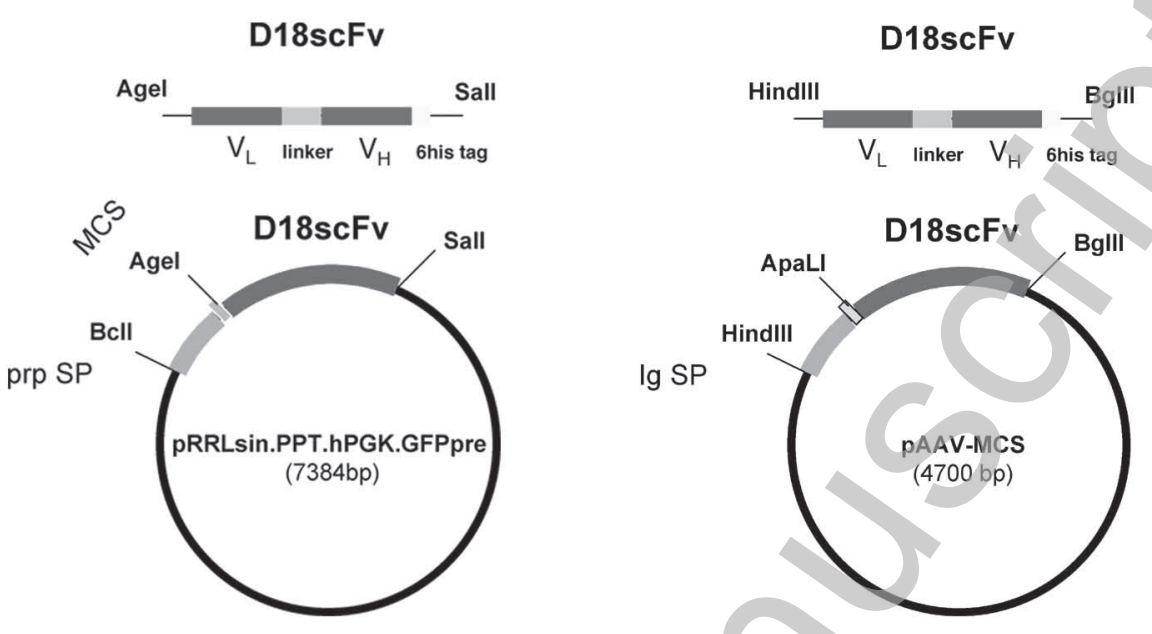

B

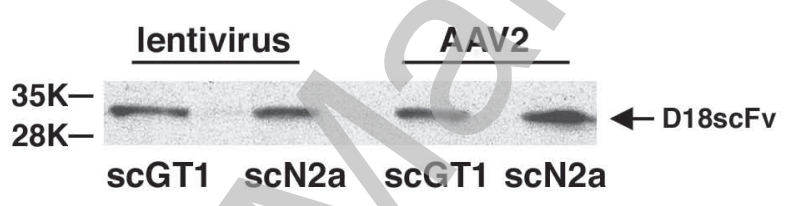

C
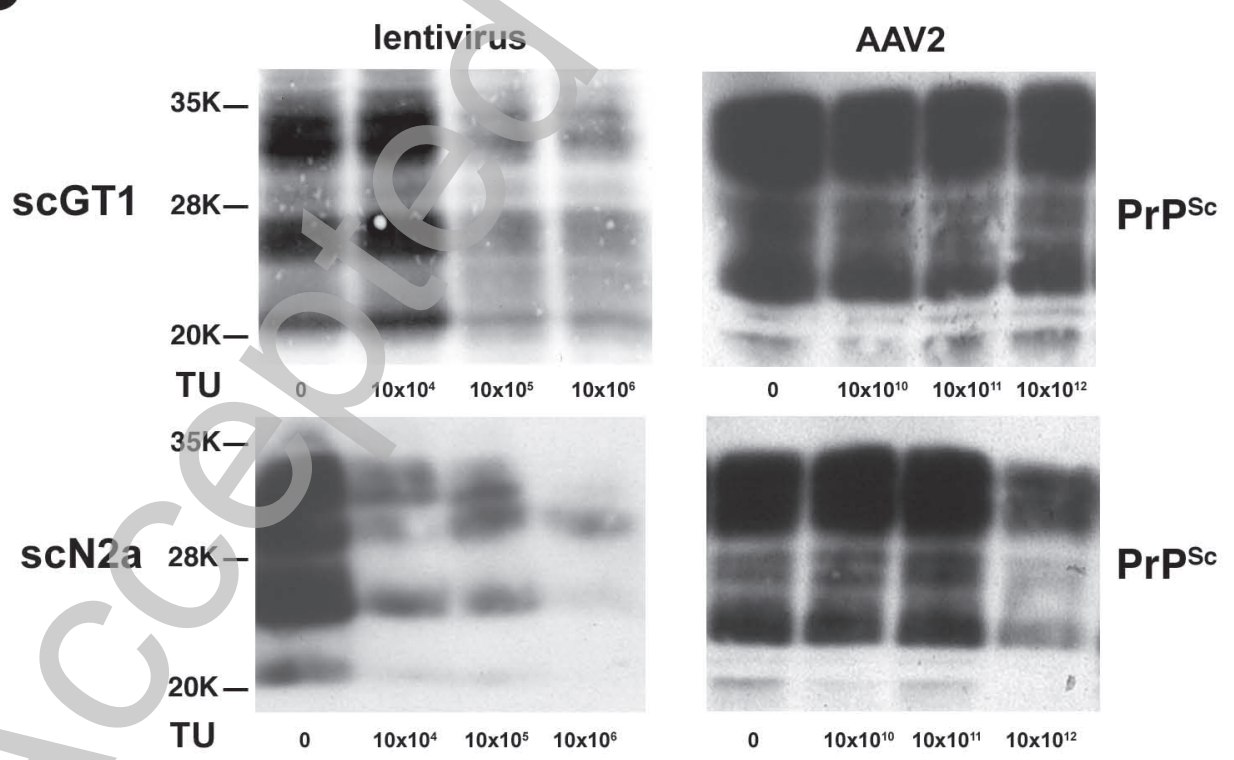

Figure 6

Licenced copy. Copying is not permitted, except with prior permission and as allowed by law. (C) 2008 The Authors Journal compilation @ 2008 Portland Press Limited 